\title{
PENGEMBANGAN MEDIA PEMBELAJARAN BERBANTUAN KOMPUTER BERBASIS INKUIRI
}

\author{
Hayati \\ Universitas Negeri Malang, Jalan Semarang 5 Malang 65145 \\ E-mail: aya0209@yahoo.co.id
}

\begin{abstract}
The Mathematics Curriculum for Junior High School encourages the use of the computer software and hardware in the teaching and learning process. As a consequence, mathematics teachers are supposed to be able to use computers as one of the learning facilities. As a matter of fact, encounter of teaching media for tessellations and the student were not interested in learning about the tessellation caused uninterested learning sources and monotonous teaching techniques the teachers use. Developing teaching media that catches the students' attention and increase their motivation is perceived as an effective solution toward the problems by Computer-assisted teaching media. The study aims at developing the valid, practical and effective tessellation's computer-assisted inquiry-based teaching media for the 9th grade students of Junior High School 5 Malang. In developing the media, the researcher adopted the 4D model (four D model) developed by Thiagarajan, Semmel and Semmel. The model involves four stages namely define, design, develop and disseminate. The results showed that the implementation of inquiry-based computer-based instructional media to meet the quality aspects in terms of product validity, product practicality, teacher activity in teaching in high categories, completeness of learning outcomes by $85 \%$ of students get a score of more than 79 , student activity in learning is quite active and students respond positively.
\end{abstract}

Keywords: computer-assisted teaching media, inquiry, tessellation

\begin{abstract}
Abstrak: Kurikulum Matematika Sekolah Menengah Pertama (SMP) mendorong penggunaan perangkat lunak dan perangkat keras komputer dalam proses belajar mengajar. Sebagai konsekuensinya, guru matematika seharusnya bisa menggunakan komputer sebagai salah satu sarana belajar. Berdasarkan fakta, pertemuan media pengajaran untuk tessellations menunjukkan bahwa siswa tidak tertarik untuk belajar tentang tessellation karena sumber belajar yang tidak menarik dan teknik pengajaran monoton yang digunakan guru. Mengembangkan media pengajaran yang menarik perhatian siswa dan meningkatkan motivasi mereka dirasakan sebagai solusi efektif terhadap permasalahan media pembelajaran berbasis komputer. Penelitian ini bertujuan untuk mengembangkan media pembelajaran berbasis penyelidikan praktis berbasis komputer yang valid, praktis dan efektif untuk Kelas 9 SMP Negeri 5 Malang. Dalam mengembangkan media, peneliti mengadopsi model 4D (empat model D) yang dikembangkan oleh Thiagarajan, Semmel dan Semmel. Model ini melibatkan empat tahap yaitu mendefinisikan, merancang, mengembangkan dan menyebarluaskan. Hasil penelitian menujukkan bahwa keterlaksanaan media pembelajaran berbantuan komputer berbasis inkuiri memenuhi aspek kualitas dalam hal validitas produk, kepraktisan produk, aktivitas guru dalam mengajar dalam katagori tinggi, ketuntasan hasil belajar sebesar $85 \%$ siswa mendapatkan skor lebih dari 79, aktivitas siswa dalam pembelajaran tergolong aktif dan siswa merespons positif.
\end{abstract}

Kata kunci: media pembelajaran berbantuan komputer, inquiry, tessellation

Salah satu kompetensi yang harus dicapai dalam Standar Kompetensi Kelulusan (SKL) Matematika 2007, yaitu memiliki kemampuan matematika dengan keterampilan ICT tertentu dengan membiasakan penggunaan software dan hardware matematika di dalam kegiatan belajar siswa (Kemendiknas, 2011). Selaras dengan hal tersebut, maka dipandang perlu untuk mengintegrasikan 
teknologi di sekolah dan pembelajaran di kelas. Keadaan ini menuntut peran guru untuk memperluas wawasan dan pengetahuan dalam memanfaatkan komputer, bahkan diharapkan mampu membuat media pembelajaran yang sesuai bagi kebutuhan pengjaran dan kebutuhan siswanya. Hal ini sesuai dengan pendekatan teori Dienes yang menyatakan, guru dapat mengembangkan daya kreativitasnya dalam merancang media pembelajaran dan sekaligus mampu menyuguhkan suatu proses belajar matematika yang bisa disesuaikan dengan kondisi sekolah dan kemampuan siswa (Bell, 1981). Dalam penelitian ini media yang dimaksud adalah media pembelajaran berbatuan komputer. Dibidang pendidikan matematika, komputer dapat digunakan untuk mengajar, belajar dan mengerjakan soal matematika. Selain itu komputer juga dapat membantu penyelidikan siswa dalam area matematika yaitu geometri. Salah satu materi dalam geometri adalah tesselasi.

Tesselasi merupakan materi wajib pada SMP. Salah satu kompetensi dasar yang harus dikuasai oleh siswa yaitu menggunakan prinsip tesselasi untuk memperoleh desain yang baik. Untuk dapat mencapai kompetensi tersebut, siswa perlu memahami konsep dan mengetahui bangun-bangun yang dapat digunakan untuk tesselasi. Penulis berpendapat bahwa pembelajaran tesselasi akan lebih optimal, jika pembelajaran materi tesselasi lebih dikembangkan dengan mengintegrasikan media yang mampu menyajikan representasi konsep abstrak melalui strategi visualisasi. Hal ini didukung oleh penelitian yang dilakukan Clements (1989) yang mengatakan bahwa, rangsangan melalui indera visual cukup efektif untuk membantu manusia dalam proses belajarnya. Komputer dengan segala kelebihannya dapat digunakan untuk membuat konsep matematika yang abstrak dan sulit menjadi lebih konkret dan mudah.

Salah satu pendekatan yang dipandang sesuai untuk penyelidikan dalam materi tesselasi adalah pendekatan pembelajaran berbasis inkuiri. Hal ini didukung oleh Piaget dan Clement bahwa pendekatan berbasis inkuiri adalah satusatunya pendekatan yang efektif untuk belajar geometri (Cerrone, 2006). Pendekatan inkuiri adalah kegiatan yang menekankan pada proses berpikir kritis dan analisis untuk mencari dan menemukan sendiri jawaban dari suatu masalah yang dipertanyakan (Sanjaya, 2008). Siswa belajar geometri dan ruang tidak hanya dengan observasi pasif melainkan, siswa sendiri harus terlibat menyelidiki konsep-konsep untuk menentukan sifat-sifat dasar yang berhubungan dengan bangunbangun yang perspektif.

Tujuan penelitian pengembangan ini adalah untuk menghasilkan media pembelajaran berbantuan komputer berbasis inkuiri pada materi tesselasi untuk siswa Kelas IX SMP yang berkualitas, valid, praktis dan efektif, dengan spesifikasi produk yang diharapkan: (1) media pembelajaran berbantuan komputer yang dibuat dengan menggunakan aplikasi Macromedia Flash; (2) dilengkapi dengan lembar kerja siswa (worksheet); (3) bahasa yang digunakan adalah Bahasa Inggris; dan (4) dilengkapi oleh bahan penyerta berbentuk cetak (print out), yaitu: Buku Panduan Penggunaan Media Pembelajaran Berbantuan Komputer Berbasis Inkuiri pada Materi Tesselasi di Kelas IX SMP. Dengan tersedianya media pembelajaran berbantuan komputer ini, dapat memperkaya media pembelajaran yang dapat dimanfaatkan bagi pengajar (guru) untuk pembelajaran di kelas, dapat membantu siswa dalam belajar tesselasi dan bagi pengembang lainnya dapat merupakan inspirasi untuk mengembangkan lebih lanjut media pembelajaran ini.

\section{METODE}

Penelitian ini merupakan penelitian pengembangan (research and development). Model pengembangan yang akan digunakan dalam penelitian pengembangan perangkat pembelajaran ini adalah model konseptual 4D (four D model) yang dikembangkan oleh Thiagarajan, Semmel, \& Semmel (1974) terdiri dari empat tahap, yaitu: define, design, develop, dan disseminate. Penelitian pengembangan ini tidak melakukan prosedur sampai tahap disseminate.

Adapun prosedur penelitian dan pengembangan pada tiap-tiap tahap adalah: (1) tahap define, langkah-langkah yang dilakukan yaitu, analisis permulaan (front-end analysis), analisis siswa (learner analysis), analisis konsep (consept analysis), analisis tugas (task analysis) dan specifikasi tujuan pembelajaran (specifying instructional objectives); (2) tahap design, langkahlangkah yang dilakukan yaitu merancang tes acuan 
patokan (constructing criterion-referenced test), pemilihan media (media selection), pemilihan format (format selection), perencanaan awal (initial design); dan (3) tahap develop, kegiatan yang dilakukan dalam tahap ini adalah validasi ahli dan uji keterbacaan. Gambar 1 merupakan diagram alir (flow chart) prosedur pengembangan penelitian.

Ujicoba produk dalam penelitian pengembangan ini dilakukan terhadap ujicoba perorangan, ujicoba kelompok kecil, dan ujicoba lapangan terbatas. Kegiatan yang dilakukan pada ujicoba perorangan dan ujicoba kelompok kecil bertujuan untuk memperoleh masukan yang dapat digunakan untuk memperbaiki produk yang dikembangkan. Sedangkan pada tahap ujicoba lapangan terbatas, dilakukan ujicoba produk yang dikembangkan terhadap sekelompok besar calon pengguna produk sebelum program tersebut dalam situasi pembelajaran yang sesungguhnya. Sekelompok besar calon pengguna pada penelitian ini adalah ujicoba dilakukan terhadap satu kelas (secara klasikal). Pada kegiatan ujicoba lapangan terbatas ini, juga dilakukan kegiatan pengamatan tehadap keterlaksanaan pembelajaran dan pengamatan aktivitas siswa oleh beberapa observer. Kegiatan ini dilakukan untuk mengetahui kepraktisan dan keefektifan produk yang dikembangkan.

Subjek uji coba pada penelitian ini adalah siswa Kelas VIII sekolah menengah pertama (SMP) semester 2, sedangkan lokasi penelitian di SMP Negeri 5 Malang. Uji coba melibatkan satu guru mitra sebagai guru yang mensosialisasikan perangkat, dua atau tiga orang guru yang lain masing-masing sebagai pengamat. Sedangkan yang dimaksudkan validator pada penelitian ini adalah beberapa orang pakar/ ahli pendidikan terhadap perangkat pembelajaran yang dikembangkan. Instrumen yang digunakan untuk mengumpulkan data dalam penelitian pengembangan media pembelajaran berbantuan komputer berbasis inkuiri pada materi tesselasi ini berupa: (1) lembar validasi media dan perangkat pembelajaran; (2) lembar pengamatan keterlaksanaan model; (3) lembar pengamatan aktivitas siswa; dan (4) angket respons siswa.

diagram alir (flow chart) prosedur pengembangan penelitian

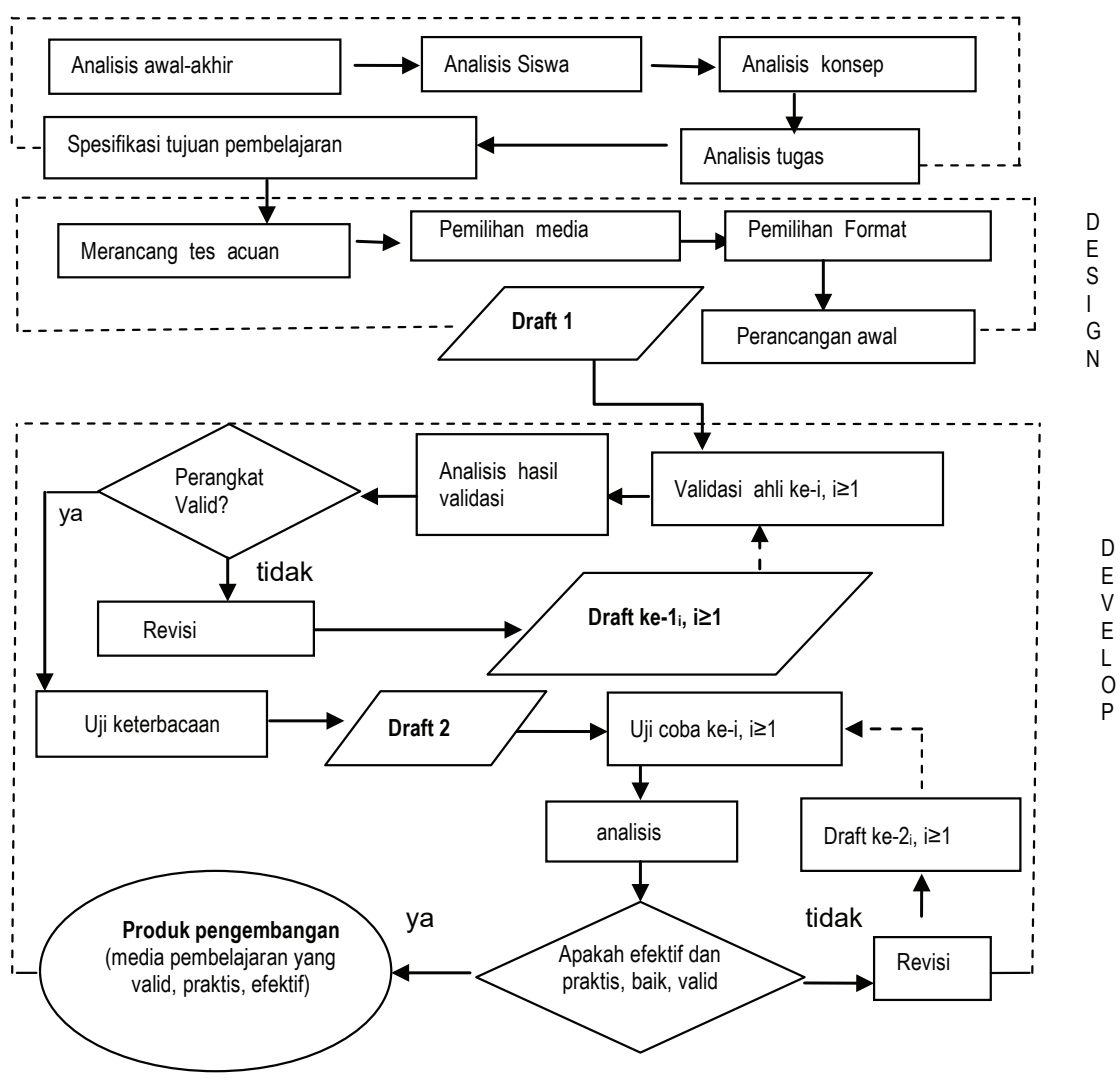

Gambar 1 Prosedur Pengembangan Penelitian 
Validitas perangkat pembelajaran yang dikembangkan ditentukan oleh penilaian validator. Media pembelajaran dikatakan valid jika dinyatakan valid oleh validator. Kepraktisan perangkat pembelajaran yang dikembangkan ditentukan dengan melihat kenyataan di lapangan hasil keterlaksanaan perangkat pembelajaran yang dikembangkan menunjukkan bahwa hasil pengamatan tentang keterlaksanaan memenuhi katagori tinggi. Sedangkan media pembelajaran dikatakan efektif jika memenuhi indikator keefektifan meliputi: (1) ketuntasan belajar; (2) aktivitas siswa dalam katagori sangat aktif atau aktif; dan (3) respons siswa dalam katagori positif.

\section{HASIL}

Hasil penelitian pengembangan adalah media pembelajaran berbantuan komputer berbasis inkuiri pada materi tesselasi yang berkualitas yaitu yang memenuhi aspek-aspek kualitas: (1) kevalidan produk hasil pengembangan media pembelajaran dapat ditinjau dari kevalidan tiap komponennya, dari hasil analisis data yang telah dilakukan terhadap penilaian ahli diperoleh nilai rata-rata total semua komponen adalah 3,24 maka sesuai dengan kriteria kevalidan dapat dikatakan dalam katagori valid; (2) kepraktisan produk hasil pengembangan dilihat dari hasil pengamatan keterlaksanaan perangkat pembelajaran menunjukkan bahwa semua aspek atau komponen pada setiap fase dalam perangkat pembelajaran terlaksana sesuai petunjuk aktivitas pada saat guru melaksanakan pembelajaran di kelas; (3) sedangkan dari hasil analisis data yang telah dilakukan terhadap penilaian pengamat diperoleh nilai rata-rata keseluruhan aspek pengamatan terhadap keterlaksanaan perangkat pembelajaran yang diamati dari aktivitas guru mengajar di kelas adalah 3,44 maka sesuai dengan kriteria kepraktisan dapat dikatakan dalam katagori tinggi; dan (4) keefektifan produk hasil pengembangan dilihat dari ketuntasan hasil belajar siswa juga memenuhi lebih dari $85 \%$ siswa mendapatkan skor lebih dari 79 dan jika ditinjau dari hasil pengamatan aktivitas siswa dalam pembelajaran diperoleh nilai rata-rata seluruh aktivitas siswa adalah 3,38 dapat dikatakan bahwa aktivitas siswa dalam pembelajaran menggunakan media pembelajaran berbantuan komputer berbasis inkuiri pada materi tesselasi dalam katagori aktif.
Sedangkan jika berdasarkan hasil analisis angket respon siswa terhadap: media pembelajaran berbantuan komputer, situasi pembelajaran, dan pengalaman belajar, peroleh nilai rata-rata seluruh responden adalah 2,36 maka dapat dikatakan bahwa respon siswa terhadap pembelajaran dengan menggunakan media pembelajaran berbantuan komputer adalah positif.

\section{PEMBAHASAN}

Salah satu pendekatan yang dipandang sesuai untuk penyelidikan dalam materi tesselasi adalah pendekatan pembelajaran berbasis inkuiri. Hal ini didukung oleh Piaget dan Clement yang menyatakan bahwa pendekatan berbasis inkuiri adalah satu-satunya pendekatan yang efektif untuk belajar geometri (Cerrone, 2006). Pendekatan inkuiri adalah kegiatan yang menekankan pada proses berpikir kritis dan analisis untuk mencari dan menemukan sendiri jawaban dari suatu masalah yang dipertanyakan (Sanjaya, 2008). Media komputer yang dikembangkan membantu siswa untuk mengkonstruk tentang definisi dan prinsip tesselasi itu melalui aktivitas-aktivitas inkuiri yang tecantum dalam lembar kerja siswa. Fakta ini sesuai dengan pandangan teori konstruktivisme yang melandasi inkuiri bahwa pengetahuan diterima dalam pikiran siswa melalui proses perubahan konstruksi aktif siswa (Bell, 1981). Selain itu media pembelajaran berbantuan komputer ini juga membantu siswa melakukan aktivitas mengecek/ menguji, mencari bukti-bukti atas kebenaran suatu ide atau jawaban sementara atas pertanyaan Media pembelajaran berbantuan komputer ini juga membantu siswa untuk menciptakan desain tesselasi. Dalam media pembelajaran komputer ini disediakan bermacam-macam segi beraturan sehingga siswa tidak memerlukan waktu yang lama dalam membuat segi beraturan secara manual dan tersedia beraneka ragam warna yang menarik.

Berdasarkan hasil penelitian di atas, dapat diketahui bahwa keterlaksanaan media pembelajaran berbantuan komputer berbasis inkuiri pada materi tesselasi sesuai dengan rancangan pembelajaran yang dibuat menunjukkan bahwa aktivitas guru dalam mengajar dalam katagori tinggi. Hal ini menunjukkan bahwa pengembangan media ini mampu mengaktifkan cara mengajar guru. Apabila dilihat dari ketuntasan hasil belajar 
siswa, dapat diketahui juga bahwa $85 \%$ siswa mendapatkan skor lebih dari 79 dan aktivitas siswa dalam pembelajaran tergolong aktif. Adapun hasil respon siswa mengungkapkan bahwa pengembangan media pembelajaran berbantuan komputer berbasis inkuiri pada materi tesselasi, diterima dengan positif. Hal ini berarti siswa menerima dengan baik pengembangan media yang telah dilakukan. Hasil penelitian ini juga didukung oleh penelitian yang dilakukan Clements (1989) yang mengatakan bahwa, rangsangan melalui indera visual cukup efektif untuk membantu manusia dalam proses belajarnya. Oleh karena itu, siswa menerima pengembangan yang ada secara positif, hasil belajar siswa juga tinggi dan aktivitas siswa juga tergolong aktif.

Media pembelajaran yang digunakan oleh guru akan mempengaruhi gaya belajar peserta didik (Gunawan dan Benty, 2007). Ketepatan dan kepraktisan media pembelajaran yang digunakan oleh guru harus melalui penilaian yang komprehensif menyangkut media tersebut (Gunawan, 2011). Media yang dekat dengan lingkungan belajar siswa akan memudahkan siswa dalam memahami materi yang disampaikan oleh guru, sehingga guru juga dapat memadukan media berbasis teknologi informasi dengan kearifan lokal (Gunawan, 2012; Gunawan, 2013). Media pembelajaran yang dikembangkan guru juga seyogyanya mampu mengembangkan proses pembelajaran yang mengarah pada pembentukan karakter mandiri, disiplin, bertanggung jawab, sekaligus menghargai orang lain (Mursidik, dkk., 2013; Gunawan, 2014). Kepala sekolah bersama guru memiliki kewajiban dalam mengembangkan sekolah yang berbasis teknologi informasi dengan berwawasan kearifan lokal (Gunawan, 2015; Gunawan, 2016).

\section{SIMPULAN DAN SARAN}

Berdasarkan paparan di atas, dapat disimpulkan bahwa keterlaksanaan media pembelajaran berbantuan komputer berbasis inkuiri memenuhi aspek kualitas dalam hal validitas produk, kepraktisan produk, aktivitas guru dalam mengajar dalam katagori tinggi, ketuntasan hasil belajar sebesar $85 \%$ siswa mendapatkan skor lebih dari 79, aktivitas siswa dalam pembelajaran tergolong aktif dan siswa merespons positif. Hasil penelitian pengembangan sangat disarankan untuk digunakan dalam pembelajaran di kelas, agar siswa dapat terlibat secara aktif dalam proses pembelajaran. Hal tersebut memungkinkan konstruksi pemahaman konsep oleh siswa, sehingga penyelenggaraan pembelajaran berbasis inkuiri dapat tercapai produk pengembangan ini dirancang untuk keperluan pembelajaran di sekolah yang perlu penyesuaian dengan kondisi setempat.

\section{DAFTAR RUJUKAN}

Bell, F. H. 1981. Teaching and Learning Mathematics in Secondary School. Iowa: Wm. C Brown Company.

Cerrone, L. K. 2006. Tessellations: Lessons for Every Age, (Online), (http://etd.ohiolink. edu/send-pdf.cgi/Cerrone\%20Kathryn\%20L. pdf?acc_num=akron11514279512/05/2010), diakses 2 Mei 2016.

Clements, D. H., \& Bohista, M. T. 1989. Geometry and Spatial Reasoning. Dalam Grows, D. A. (Eds.), Handbook of Research on Mathematics Teaching and Learning. New York: MacMillan Publishing Company.

Gunawan, I. 2011. Evaluasi Program Pembelajaran. Jurnal Pendidikan, 17(1), 52-70.

Gunawan, I. 2012. Mengembangkan Karakter Bangsa Berdasarkan Kearifan Lokal. Prosiding Seminar Nasional Meretas Sekolah Humanis untuk Mendesain Siswa Sekolah Dasar yang Cerdas dan Berkarakter, PGSD FKIP Universitas Muhammadiyah Surakarta, 6 Mei.

Gunawan, I. 2013. Pengembangan Buku Pedoman Microteaching Berbasis Lesson Study. Jurnal Pendidikan, 19(1), 1-26.

Gunawan, I., dan Benty, D. D. N. 2007. Musyawarah Guru Mata Pelajaran dan Kemampuan Mengelola Kelas untuk Meningkatkan Motivasi Belajar Siswa. Manajemen Pendidikan, 20(1), 21-31.

Gunawan, I. 2014. Analisis Dampak Supervisi Pendidikan terhadap Perkembangan Masyarakat dan Ilmu Pengetahuan dan Teknologi. Prosiding Seminar Nasional Pendidikan Revitalisasi Manajemen 
Pendidikan Nasional Menuju Perbaikan Mental, Jurusan Administrasi Pendidikan Universitas Negeri Malang, 8 Desember.

Gunawan, I. 2015. Strategi Meningkatkan Kinerja Guru: Apa Program yang Ditawarkan oleh Kepala Sekolah? Prosiding Seminar Nasional Pengembangan Karir Tenaga Pendidik Berbasis Karya Ilmiah, Fakultas Ilmu Pendidikan Universitas Negeri Malang, 23 Agustus.

Gunawan, I. 2016. Pasaran: Menggali Nilainilai Permainan Tradisional dalam Mengembangkan Sifat-sifat Kepemimpinan Pendidikan. Jurnal Studi Sosial, 8(1), 55-64. Mursidik, E. M., Tryanasari, D., dan Gunawan, I. 2013. Pengembangan Buku Pedoman Microteaching Berbasis Lesson Study. Jurnal Pendidikan, 19(1), 1-26.
Kemendiknas. 2011. Standar Isi dan Struktur Kurikulum Mata Pelajaran Matematika SMP-BI. Jakarta: Depdiknas.

Sanjaya, W. 2008. Perencanaan dan Desain Sistem Pembelajaran. Jakarta: Predana Media Group.

Thiagarajan, Semmel, \& Semmel. 1974. Instructional Development for Training Teachers of Exceptional Children. Minneapolis, Minnesota: MacMillan Publishing Company. 